\title{
The Effect Catalyst Natural Zeolite of Lampung On The Synthesis Of $\alpha$-Terpineol From Turpentine
}

\author{
Herti Utami ${ }^{*}$, Simparmin Br. Ginting ${ }^{1}$, Dwi Derti Sulistiowati ${ }^{1}$ and Ria Putri Hermiyati ${ }^{1}$
}

\begin{abstract}
The major component of turpentine is $\alpha$-pinene. Alpha pinene can be hydrated using an acid catalyst to produce $\alpha$ terpineol. It can be used as a perfume, anti -insect, and disinfectants. The using of heterogeneous catalysts as natural zeolite can be a new alternative to replacehomogeneous catalysts. The purpose of this study was to determine the effect of zeolite catalysts and the reaction time which resulting the highest conversion on hydration reactions of turpentine to $\alpha$-terpineol. Parameters were the effect of catalyst concentration of $(5 \%, 10 \%$ and $15 \%)$ and the reaction time (60 minutes, 120 minutes and 180 minutes). The turpentine, aquadest and isopropyl alcohol were reacted in the three neck flask at the temperature of $70^{\circ} \mathrm{C}$. The result of this study showed that the best condition the hydration of turpentine $\alpha$-terpineol was achieced at $15 \%$ catalyst concentration and the reaction time of 180 minutes. The convertion was obtained to be $4.875 \%$.
\end{abstract}

Keywords - Turpentine, Hydration, Alpha terpineol, Catalys,Natural Zeolite.

\section{INTRODUCTION}

$\mathbf{T}$ urpentine from Indonesia contains $65-85 \% \alpha$-pinene, $1 \%$ camphene, $1-3 \% \beta$-pinene, $10-18 \%$ 3-carene and 1-3\% limonene. The major component turpentine is $\alpha$-pinene. Alpha pinene can be hydrated using an acid catalyst to $\alpha$ terpineol. Alpha terpineol can be used as perfume, antiinsect, anti-fungal, and disinfectant. The reaction between $\alpha$-pinene and water to be $\alpha$-terpineol is as follows

$$
\mathrm{C}_{10} \mathrm{H}_{16}+\mathrm{H}_{2} \mathrm{O} \longrightarrow \mathrm{C}_{10} \mathrm{H}_{18} \mathrm{O}
$$

The synthesis $\alpha$-terpineol from $\alpha$-pinene with the catalyst has been studied by several researchers. Arias et.al. (2000) studied the hydration of turpentine to $\alpha$-terpineol using a dealumination faujasite as catalyst. The product of $\alpha$ terpineol with the highest selectivity was $44 \%$ at $70 \%$ conversion. Nuritasari (2013) has conducted $\alpha$-pinene hydration to $\alpha$-terpineol production by using natural zeolite catalysts. The TCA-ZA catalyst which has been used was washed with aquadest and reused with $15.36 \%$ reaction result. Amilia et. al (2013) has done the research the effect of Amilia et. al (2013) has done the research the effect of

Manuscript received June 20, 2015.

${ }^{1}$ Chemical Engineering Departement, Universitas Lampung, 35145 Lampung, Indonesia (corresponding author to provide phone: +6281354083620; e-mail:herti.utami@ eng.unila.ac.id). temperature on the hydration reaction of $\alpha$-pinene to $\alpha$ terpineol with natural zeolite catalyst and the best result was obtained at the temperature of $70^{\circ} \mathrm{C}$ and the conversion was $68.53 \%$.

The catalysts used in the $\alpha$-pinene hydration reaction during this homogeneous catalyst were chloroacetic acid, oxalic acid and trichloroacetic acid (TCA). Utami (2010) studied the hydration of $\alpha$-terpineol from turpentine using chloroacetic acid as catalyst. The best $\alpha$-terpineol conversion was $54.13 \%$ at the temperature of $80^{\circ} \mathrm{C}$ and the reaction time was 240 minutes. Daryono (2015) who has done $\alpha$-pinene synthesis to $\alpha$-terpineol by using sulfuric acid catalyst obtained the highest $\alpha$-terpineol conversion of $57.05 \%$ and the yield of $67.79 \%$ at temperature of $70^{\circ} \mathrm{C}$. In fact, the use of the homogeneous catalyst is corrosive and thisis not environmental friendly, so it is necessary to use a more environmental friendly catalyst. One alternative catalyst that can be used is a heterogeneous catalyst such as natural zeolite. That is more economical, easy to obtain, and environmental friendly. This research was conducted for the synthesis of $\alpha$-terpineol from turpentine oil by using heterogeneous solid catalyst, natural zeolite, especially natural zeolite of Lampung.

\section{II.MATERIALS AND METHODS}

\section{A.Chemical}

Turpentine obtained from Perhutani Semarang. Isopropyl, dichloromethane, $\mathrm{HCl}, \mathrm{Na}_{2} \mathrm{CO}_{3}$, and $\mathrm{Na}_{2} \mathrm{SO}_{4}$

\section{B. Catalyst}

The catalyst used was natural zeolite of Lampung which has been activated. The natural zeolite of Lampung obtained by CV. Minatama.

\section{Procedure}

Procedure of this research includes the initial treatment of natural zeolite.That was activated with physical and chemical treatment. In the preparation step, the natural zeolite of Lampung was sieved with a size of 100 mesh, then washed with aquadest that aim to dissolve the dirt 
on the zeolite surface. Then the zeolite was dried in an oven with the temperature of $200^{\circ} \mathrm{C}$ for 2 hours. After the zeolite preparation completed, the natural zeolite of Lampung as many of 300 grams was soaked with $\mathrm{HCl} 4$ $\mathrm{M}$ solution of $1 \mathrm{~L}$. Then the natural zeolite of Lampung after dissolved with $\mathrm{HCl}$ was washed with aquadest to remove $\mathrm{Cl}$ - ions until the $\mathrm{pH}$ becomes neutral. After that the zeolite was dried in an oven with the temperature of $110^{\circ} \mathrm{C}$ for 3 hours. Then natural zeolite of Lampung calcined in a furnace with the temperature of $400^{\circ} \mathrm{C}$ for 3 hours. Zeolite can already be used as a catalyst. The natural zeolite of Lampung before activation, after activation and after reaction was analyzed with Branaeur Emmet Telle (BET), Fourier Transform Infrared (FTIR) and X-ray Flourenscence (XRF) to know the content of $\mathrm{Si} / \mathrm{Al}$, surface area and the acid sites at Lampung natural zeolite.

The hydration reaction was carried out in a three-neck flask that filled $20 \mathrm{~mL}$ of turpentine, $109 \mathrm{~mL}$ of aquadest, and $80 \mathrm{~mL}$ of isopropyl alcohol. The threeneck flask was equipped with a thermometer and a magnetic stirrer. The mixture was warmed up to the temperature of $70^{\circ} \mathrm{C}$. After the temperature was reached, the natural zeolite of Lampung was loaded into the flask. The mixture was stirred and the reaction time was started to be calculated. A sample was taken at every reaction time of 60 minutes, 120 minutes and 180 minutes at each concentration of natural zeolite of Lampung 5\%, 10\% and 15\%. The product of the turpentine hydration reaction was introduced into the centrifuge for 15 minutes at a rotation speed of $350 \mathrm{rpm}$. The sample of centrifuge results was filtered and the natural zeolite of Lampung was not included in the product.The neutral step, the product was poured into a separating funnel to separate the top layer (product) and the bottom layer (reactants). The product has been separated, then washed with aquadest in a separation funnel. The washed product was added $10 \% \mathrm{Na}_{2} \mathrm{CO}_{3}$ solution until the $\mathrm{pH}$ becomes neutral. Furthermore, the product was added 1 drop of dichloromethane solution in separating funnel. The latter process was added anhydrous $\mathrm{Na}_{2} \mathrm{SO}_{4}$ to bind the residual water and the product was filtered to separate the precipitate. The results of hydration $\alpha$-terpineol synthesis were analyzed by Gas Chromatografy (GC) and the best result was analyzed by Gas Chromatografy Mass Spectrometry (GC-MS).

\section{ANALYSIS OF RESULTS}

Zeolite may be used as a catalyst or as a catalyst support if it has a high $\mathrm{Si} / \mathrm{Al}$ content, contains acid $\left(\mathrm{H}^{+}\right)$ and absence of impurities in the pores of the zeolite that the surface area of the pore was large. To know the content of $\mathrm{Si} / \mathrm{Al}$, the surface area and the acid sites in natural zeolite of Lampung can be analyzed with Branaeur Emmet Telle (BET), Fourier Transform Infrared (FTIR) and X-ray Flourenscence (XRF). The natural zeolite of Lampung has been activated by chemical and physical treatment then it was analyzed by using BET. The surface area was 35.2564 $\mathrm{m}^{2} / \mathrm{g}$.

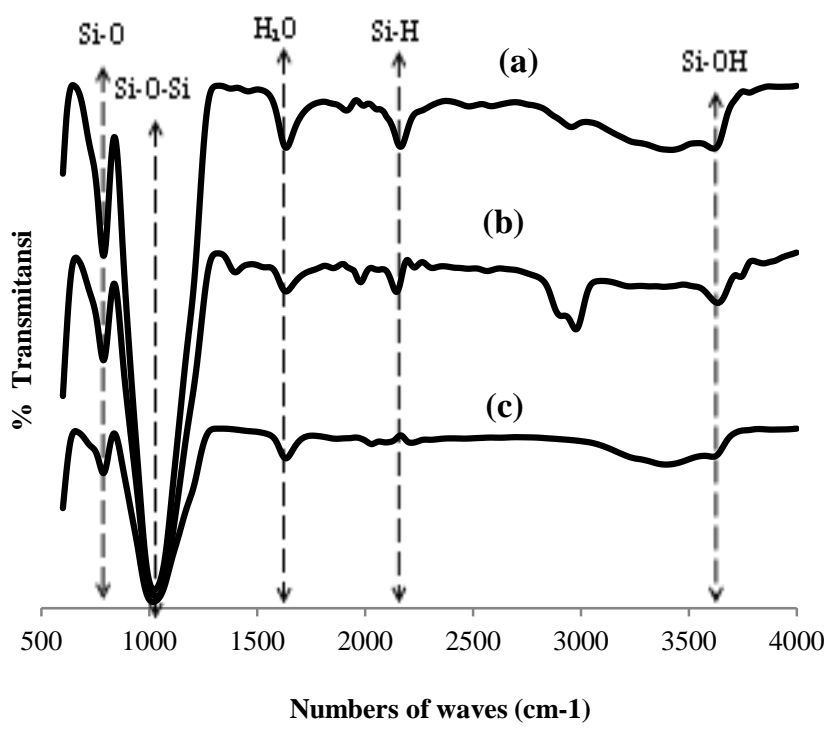

Fig 1. The results analysis FT-IR ZAL

In the Figure 1 shows the characterization results of the natural zeolite of Lampung before activation (a) and after activation (b) and after being used as a catalyst in the turpentine hydration reaction to $\alpha$-terpineol (c). The wave length indicates several peaks indicating the presence of some functional groups in the natural zeolite. Based on Figure 1. we can see the absorption of waves in zeolite (a) $787.78 \mathrm{~cm}^{-1}$, (b) $788.08 \mathrm{~cm}^{-1}$ and (c) $788.79 \mathrm{~cm}^{-1}$ which it shows the interpretation of bond absorption on the main structural unit of zeolite in the form Si-O. And then comes the absorption band of Si-O-Si vibration that is (a) 1018 $\mathrm{cm}^{-1}$, (b) $1031 \mathrm{~cm}^{-1}$ and (c) $1023 \mathrm{~cm}^{-1}$. In Fig. 1. the wave numbers (a) $3615 \mathrm{~cm}^{-1}$, (b) $3635.68 \mathrm{~cm}^{-1}$ and (c) $3618 \mathrm{~cm}^{-1}$ show the vibration of the Si-OH group (hydroxyl group). 
Furthermore the absorption bands at wave numbers (a) $1632.93 \mathrm{~cm}^{-1}$, (b) $1634.01 \mathrm{~cm}^{-1}$ and (c) $1644.00 \mathrm{~cm}^{-1}$ indicate the presence of $\mathrm{H}-\mathrm{O}-\mathrm{H}$ groups. Then the formation occurs in zeolites (b) and (c) $2146 \mathrm{~cm}-1$, where absorption at 2100-2400 cm-1 shows the uptake of Si-H (Socrates, 1994). The Si-H absorption band appears due to the activation of the zeolite with the addition of acid and $\mathrm{Si}$ appears to bind $\mathrm{H}$.

The natural zeolite of Lampung was characterized by using XRF to analyze the elements in the mineral or rock presented in Table 1.

Table 1. The result XRF natural zeolite of Lampung

\begin{tabular}{ccc}
\hline \multirow{2}{*}{ Component } & \multicolumn{2}{c}{ Concentration $(\%)$} \\
\cline { 2 - 3 } & before activation & After activation \\
\hline $\mathrm{Al}$ & 13,636 & 13,033 \\
$\mathrm{Si}$ & 75,598 & 79,746 \\
\hline \hline
\end{tabular}

Based on the results of XRF analysis shown in Table 1 , it can be seen that there was an increase of Si content in zeolite after activation, where before the activation of $\mathrm{Si}$ content in natural zeolite of Lampung was $75.598 \%$ and after activation at zeolite become $79.746 \%$. In addition to the increase in $\mathrm{Si}$ content, in zeolites also decreases $\mathrm{Al}$ levels in zeolites from $13.636 \%$ before activation to $13.033 \%$ after activation. This indicates that the activation process at natural zeolite of Lampung using $\mathrm{HCl}$ with $4 \mathrm{M}$ concentration was successful. Activation of zeolite with $\mathrm{HCl}$ addition aims for dealumination (release of $\mathrm{Al}$ from zeolite), and the dealumination can increase the $\mathrm{Si} / \mathrm{Al}$ ratio in zeolite. This is evidenced from the results of XRF in Table 1 , where the ratio of $\mathrm{Si} / \mathrm{Al}$ in natural zeolite after activation is higher than natural zeolite that has not been activated. In the unactivated natural zeolite has a $\mathrm{Si} / \mathrm{Al}$ value of 5.544 , while the $\mathrm{Si} / \mathrm{Al}$ value in the activated zeolite is 6.11 . The higher the $\mathrm{Si} / \mathrm{Al}$ value, the higher the acidity or the more acid sites in the zeolite. The increase of acid sites it will increase the activity of zeolite. According to Triantafillidis (2000) the more Al content in zeolites (Si/ Al ratio decreases) will cause the strength or total of zeolite acid sites to decrease.

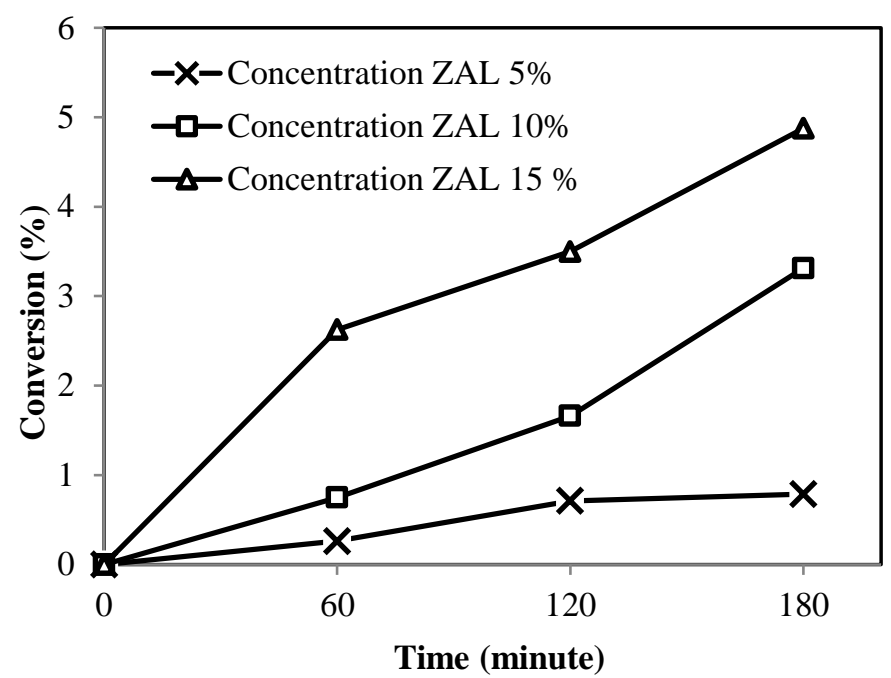

Fig 2. Effect of concentration of catalys on conversion $\alpha$-pinene to $\alpha$ terpineol

In Figure 2. it can be seen that at a zeolite concentration of $5 \%$ there was an insignificant increase of $\alpha$-terpineol conversion from $60 \mathrm{~min}$ to $180 \mathrm{~min}$, obtained by conversion of $\alpha$-pinene to the highest $\alpha$-terpineol $0.7875 \%$ at reaction time of $180 \mathrm{~min}$. At the $10 \%$ zeolite concentration increased conversion from 60 minutes to 180 minutes, where the highest conversion obtained at 180 minutes and the conversion was $3.3125 \%$. While at the concentration of $15 \%$ there was also a significant conversion increase from 60 minutes to 180 minutes with the highest conversion obtained at 180 minutes and the conversion was $4.875 \%$.

Based on the results of conversion, the concentration of catalyst natural zeolite of Lampung influences the conversion $\alpha$-pinene to $\alpha$-terpineol. As the number of catalysts or concentrations of zeolite catalysts used for turpentine hydration, the higher $\alpha$-terpineol conversion was obtained. The large number of catalysts affects the surface area of the catalyst during reaction. The more catalysts used, the more active sites will be utilized during the turpentine hydration reaction. The more active sites on the zeolite then the resulting product will increase. Although in this study there is an increase in conversions, the minor conversion was obtained. This is because the natural zeolite catalyst used has a $\mathrm{Si} / \mathrm{Al}$ value that is not too different from before activation so that the catalyst performance is less than optimal.

To get the optimum reaction time, then experiment again with addition of reaction time is 240 minutes at $15 \%$ catalyst concentration, as follows : 


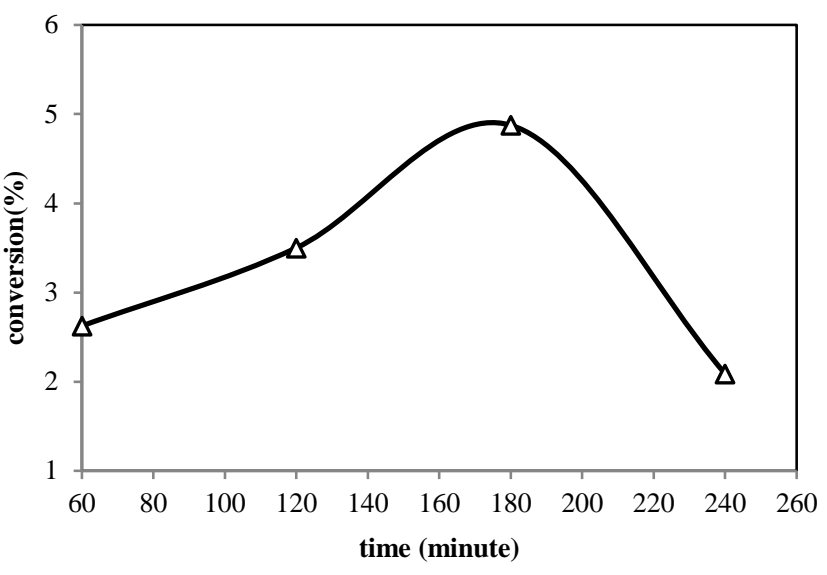

Fig 3. Effect of the reaction time on conversion $\alpha$-pinene to $\alpha$-terpineol

Based on the Figure 3. can be seen there is the possibility of the conversion of $\alpha$-terpineol at 240 minutes reaction time. Where in 60 minutes up to 180 minutes there was an increase of $4.872 \%$, but at 240 minutes the $\alpha$ terpineol conversion decreased to $2.08 \%$. Thus, it can be concluded at zeolite concentration of $15 \%$ the optimal reaction time occurred at $180 \mathrm{~min}$.

Analysis with mass spectrum (MS) is aimed to know the compound of hydration of $\alpha$-pinene for $\alpha$-terpineol production. The GC-MS spectrum results are presented in Figure 4.

Hitt:3 Entry:11024 Libray:NIST62.LB

SL:84 Formula:C10HI 80 CAS:98-55-5 MolWeight:154 Rethdex:0

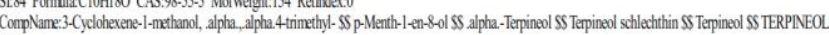

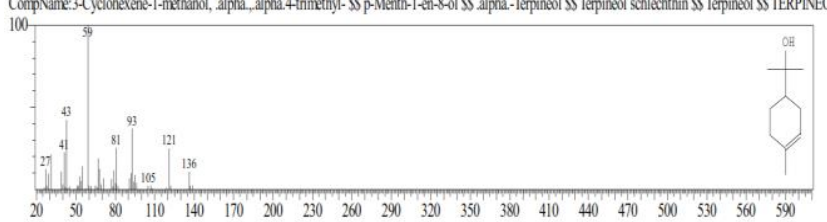

Fig 4. The result analysis of GC-MS

Based on the mass spectrum from peak 28 proves that the compound formed is $\alpha$-terpineol with a molecular weight of 154 and the molecular formula $\mathrm{C}_{10} \mathrm{H}_{18} \mathrm{O}$.

\section{CONCLUSION}

Based on the result of the research, it can be concluded that the natural zeolite of Lampung that has been activated has $\mathrm{Si} / \mathrm{Al}$ value of 6.11 and the surface area of 35.2564 $\mathrm{m}^{2} / \mathrm{g}$. The synthesis of $\alpha$-terpineol from turpentine using natural zeolite catalysts, it suggested that the best result was achieved at the catalyst concentration of $15 \%$ and the optimum reaction time of $180 \mathrm{~min}$. The conversion of $\alpha$ pinene to $\alpha$-terpineol was obtained to be $4.875 \%$.

\section{REFERENCES}

[1] Amilia, N., Siadi, Kusoro, dan Latifah, "Pengaruh Temperatur pada Reaksi Hidrasi a-pinena menjadi $\alpha$-terpineo lterkatalis Zeolit Alam Teraktivasi", Skripsi Jurusan Kimia Fakultas Matematika dan Ilmu Pengetahuan Alam, Skripsi Jurusan Kimia Fakultas Matematika dan Ilmu Pengetahuan Alam, Universitas Negeri Semarang, 2013.

[2] Arias D, Guillen Y, Lopez, C.M., and Machado, F.J., "Turpentine Oil Hydration Using Dealuminated Faujasite as Catalysts", React. Kinet. Catal. Lett., 2000, Vol. 69, No. 2., pp. 305-309.

[3] Daryono, E.D., "Sintesis $\alpha$-Pinene Menjadi $\alpha$-Terpineol dengan Menggunakan Katalis Asam Sulfat dengan Variasi Suhu Rreaksi dan Volume Etanol", Jurnal Teknik Kimia USU, 2015,Vol.4 No.2

[4] Utami, H., Budiman, A., Sutijan, Roto and Sediawan, W.B., "Synthesis of $\alpha$-Terpineol from Turpentine by Hydration in a Batch Reactor", Proceedings $17^{\text {th }}$ ASEAN Regional Symposium on Chemical Engineering, Bangkok, Thailand, November 22-23, 2010.

[5] Nuritasari, A.L., "Pengaruh Katalis Zeolit Alam Teraktivasi dan TCAZeolit Alam Dalam Reaksi Hidrasi $\alpha$-Pinena Menjadi $\alpha$-Terpineol" Skripsi Jurusan Kimia Fakultas Matematika dan Ilmu Pengetahuan Alam Universitas Negeri Semarang, 2013.

[6] Socrates, G., "Infrared Spectroscopy", Chicester: John Willey \& Sons Ltd., 1994.

[7] Triantafillidis, C., Vlessidis, A., and Evmiridis, N., "Dealuminated HY Zeolite: Influence of The Degree and The Type of Dealumination Method on Structural and Acidic Characteristics of H-Y Zeolite", Ind. Eng. Chem, 2000, Vol. 39, No. 2, pp. 307-3019. 